\title{
MUNICIPAL ACTIVITIES IN LOCAL FOOD SYSTEMS: CASE STUDY OF ZEMGALE REGION
}

Dace Kaufmane ${ }^{1}$, Dr.oec.; Liga Paula², Dr.sc.soc.; Kaspars Naglis-Liepa3 ${ }^{3}$ Dr.oec.;

Liga Proskina ${ }^{4}$, Dr.oec.; and Laura Andriana Indriksone ${ }^{5}$

1, 2, 3, 4, 5Latvia University of Life Sciences and Technologies

\begin{abstract}
According to the Actor Network Theory, the local food system is a set of interconnected processes and social agents including municipalities as a business environment. In the context of rural studies, support for local food producers is important for local communities. By content analysis of the information available on the websites of Zemgale region's municipalities and the opinions of municipal specialists on local support measures for entrepreneurs, the aim of the paper was to identify the activities of municipalities in local food systems. Within a context of local food systems, the authors revealed that municipalities in Zemgale region provide support activities in two main directions: food businesses and tourism activities. The analysis of business support measures showed that local food producers in municipalities are promoted and supported in a number of ways through branding, special events and trade facilitation, seminars and annual awards. Activities in the field of tourism revealed cooperation, involving local food producers in the tourism system and ensuring the recognition of local food products to a wider group of consumers. Integrating local food businesses into tourism routes and thematic activities, in other words making locally produced food an integral part of the tourism product, develops small and medium-sized enterprises that contribute to the socio-economic resilience and environmental sustainability of rural communities, local innovations and creativity. In Zemgale, municipal activities for support of local food producers in the context of COVID-19 crisis are strengthening rural communities thus supporting and helping entrepreneurs to adapt to changes.
\end{abstract}

Key words: Actor Network Theory, rural community, local food systems, tourism, food producers.

JEL code: Q180, Z130, R580

\section{Introduction}

The European Economic and Social Committee's opinion on "More sustainable food systems" emphasizes that producer organizations have demonstrated their resilience to shocks in agricultural markets; they also help to avoid relocation of food production. Therefore, further, even greater, sectoral and regional support aimed at fostering cooperation between producers and cooperatives, especially small cooperatives, is essential. In particular, special attention should be paid to sectors and regions with a low level of cooperation (Official Journal of ..., 2016). Local food initiatives are promoted as opposition to the disempowering social and economic effects of globalization; thus, revitalisation of rural communities, benefits for local farmers and environment are expected outcomes of reduced physical distance between producers and consumers (Fonte M., 2008:203). In this regard, community resilience can be understood as the existence, development and engagement of community resources by community members who intentionally develop personal and collective capacity to respond to and influence change, to sustain and renew the community, and to develop new trajectories for the communities' future (Roberts E., Townsend L., 2016).

The local food system (LFS) is not limited to food production, processing and marketing. More broadly, the system involves actors representing food production, processing, consumption, marketing, advertising, branding, training and education, policy making, regulations and norms as well as other elements. According to the Actor Network Theory (ATR), the world is made of multiple networks of heterogeneous, complex and dynamic human and nonhuman actors (Lee K. C. L., Newell J. P., Wolch J., Schneider N.,

3 ef08389@llu.lv

4 Liga.Proskina@llu.Iv

5 indriksone.laura@inbox.lv 
Joassart-Marcelli P., 2014; Latour B., 1997; Chesterman A., 2006) from which all affect change. The human actors are living entities and the non-human actors represent technologies, institutions and corporations. The ATR highlights the characteristics of actors: the ability to trigger action and the ability to attract other actors to reach their goals (Devi W. P, Kumar H., 2017). In other words, anyone attracting, linking and combining other elements is considered as an actor, every element involving a space around itself makes other elements dependent on itself and treats another's will in its actions and rhetoric (Callon M., Latour B., 1981). Actors' behavior is treated as goals, involvement in reality-building, which in turn is the result of agent interaction (Bruun H., Hukkinen J., 2003). A network of actors is a set of socially important nodes (units) connected by one or more relationships in the models being studied. These units are usually persons or organisations that may be connected to other units (Marin A., Wellman B., 2009). The concept of a network of actors allows to eliminate the difference between micro and macro; the network is never larger another network, it is simply longer or more intensively connected. It is important to follow how a particular actor becomes strategic because of a number of connections it runs and how it loses its importance by losing connections. The purchase of local food increases the income for both the local producers and wider community, increases employment through the multiplier effect at the local level. The aim of the paper is to identify the activities of municipalities in local food systems. By analysing the websites of municipalities and the opinions of municipal specialists on support for entrepreneurs, the objective of the paper is to look at the main directions of municipal support for food producers.

\section{Research results and discussion}

\section{Research methodology}

Content analysis was carried out to investigate and describe municipal activities in LFS in rural communities. As shown in Figure 1, there are 20 rural municipalities in Zemgale region as well as two republican cities (Jelgava and Jekabpils) (Zemgale Planning..., 2017). As the study focuses on rural areas, the websites of 20 rural municipalities (Aizkraukle, Akniste, Auce, Bauska, Dobele, Iecava, Jaunjelgava, Jelgava, Jekabpils, Koknese, Krustpils, Nereta, Ozolnieki, Plavinas, Rundales, Sala, Skriveri, Tervete, Vecumnieki, Viesite) were analysed from January to February 2021.

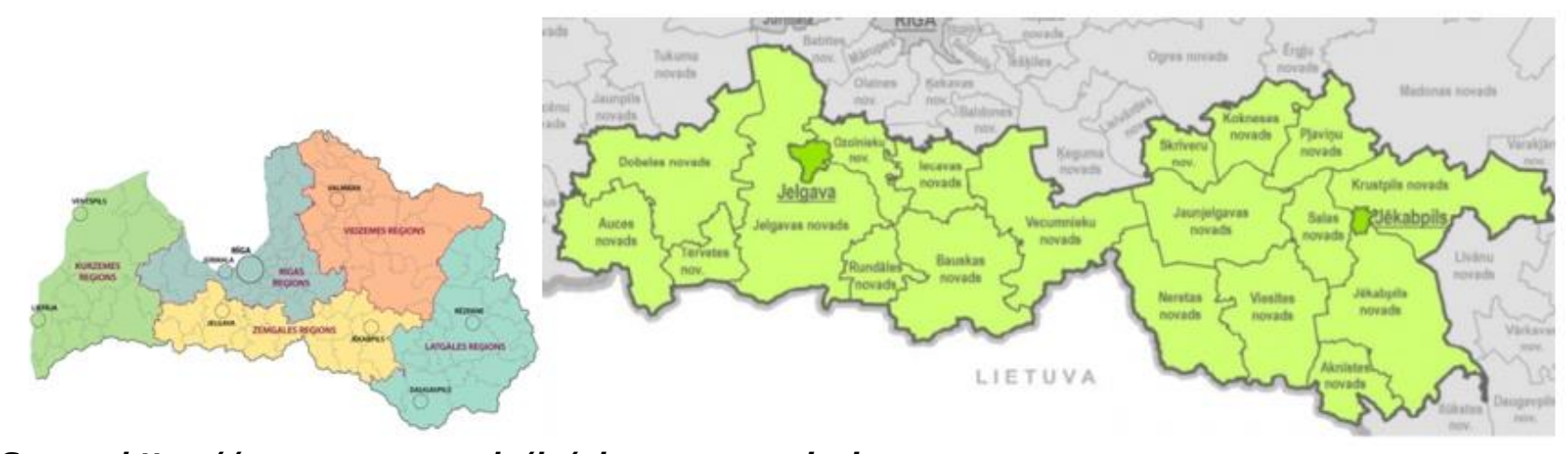

Source: https://www.varam.gov.lv/lv/planosanas-regioni

Fig. 1. Location of Zemgale region

From January to March 2021, a short online survey in all Latvian municipalities was conducted to clarify the views of local government specialists on the support of food producers and influencing factors. Of the 110 invitations sent, 32 replies were received. 


\section{Food producers in Zemgale region}

The food sector is the largest in the EU in terms of both employment and impact on GDP thus the food is at the heart of the society: it depends on and affects natural resources, it has an impact on public health and it plays a key role in the European economy (Official Journal of the European Union, 2016). In Latvia, food production businesses are relatively evenly distributed and cover all regions and municipalities, including rural areas (Figure 2).

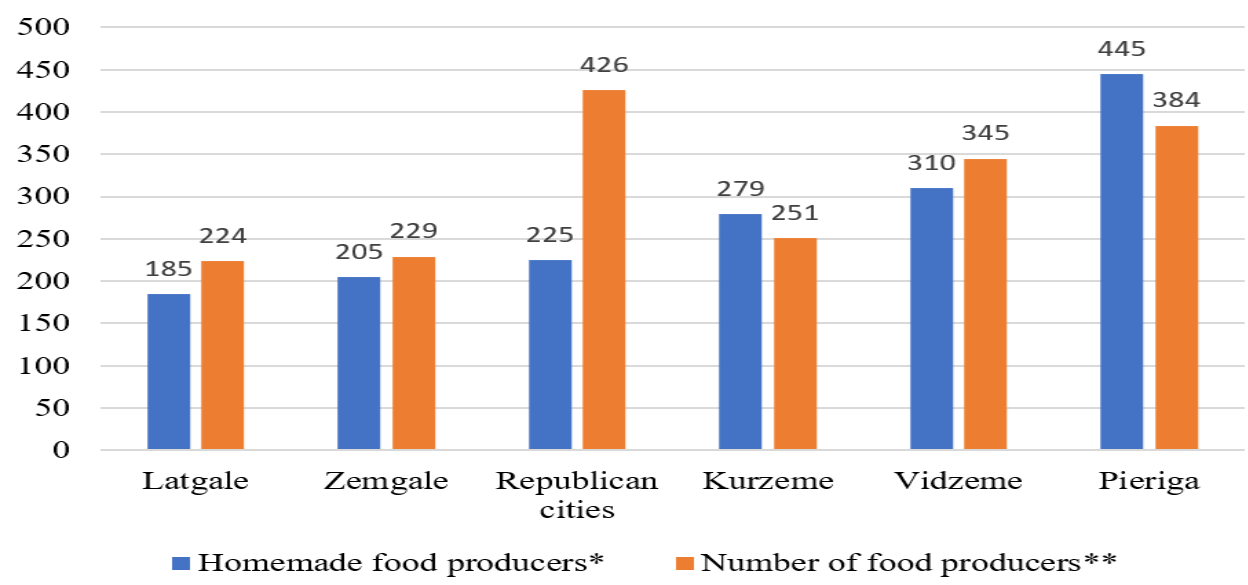

* The type of activity indicated in the register of the Food and Veterinary Service (FVS)

** The type of activity indicated in the register of the FVS - 02, 07, 08, 09, 10,12,13,16, 18, 19,20,21, 22

Source: author's calculations based on the data of the FVS

Fig. 2. Number of food producers in Latvia, 2021

There are fewer producers in Latgale and Zemgale regions; most of them are concentrated in the capital city and its agglomeration as well as in the republican cities. More detailed information on the number of producers in Zemgale is shown in Figure 3.

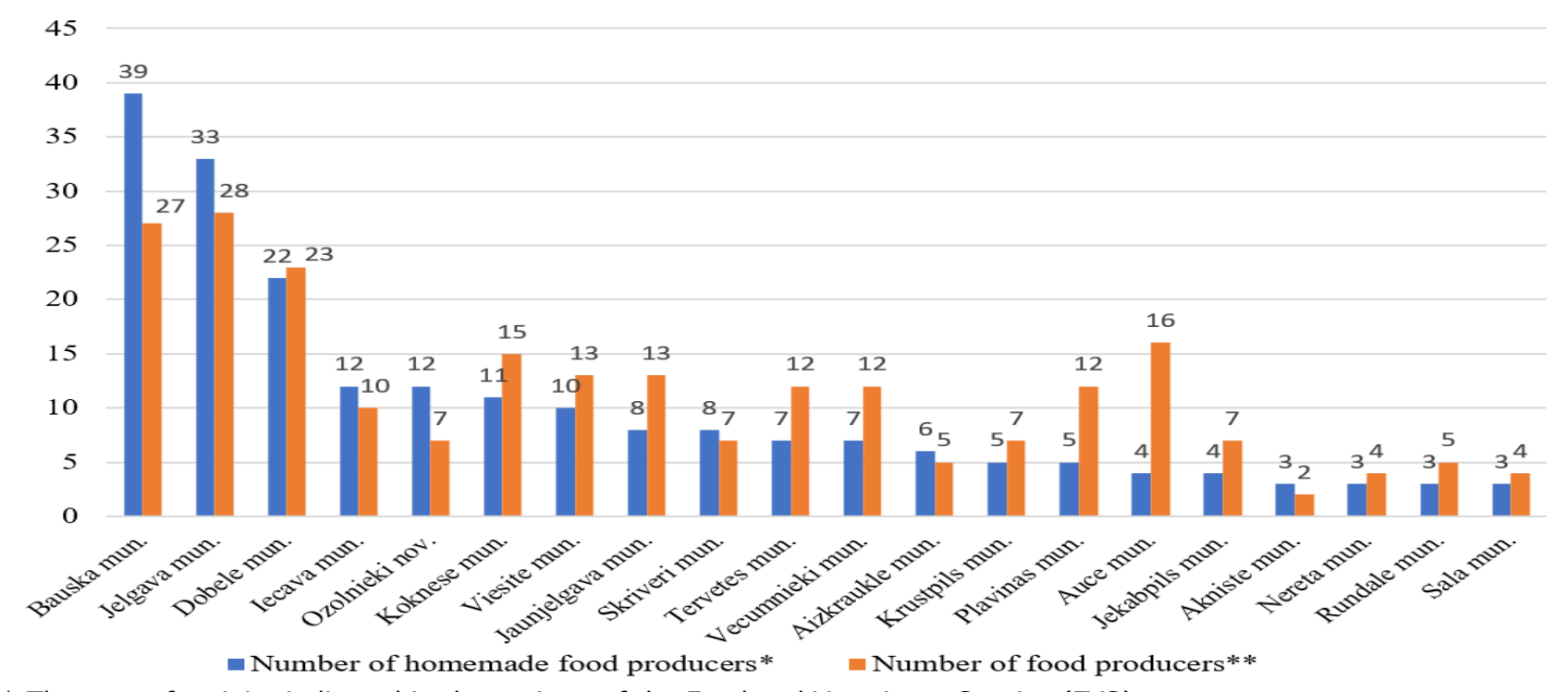

* The type of activity indicated in the register of the Food and Veterinary Service (FVS)

** The type of activity indicated in the register of the FVS - 02, 07, 08, 09, 10,12,13,16, 18, 19, 20, 21, 22

Source: author's calculations based on the data of the FVS

Fig. 3. Number of food producers in rural municipalities in Zemgale region, 2021

In LFS the products are produced, processed, marketed and consumed over a relatively short geographical distance, thus having a number of economic benefits that have a significant positive effect on the local economy. The effects are related to diversification of the rural economy, promotion of greater 
economic independence, boosting local potential and improvement of the area's image. The transition to more resilient and sustainable food systems therefore covers all interlinked activities involving food production, processing, transport, storage, trade and consumption. The preservation of the family farm model in Europe is also essential, and generational succession in farms should be promoted in this context in order to face the challenge of an ageing population. This would have a positive impact on job creation in rural areas. It is also important to ensure diverse agricultural production in all regions of the EU (Official Journal of ..., 2016). Great diversity in food production is represented in Zemgale region as both food producer businesses and home producers offer all product groups (see Figure 4); however, given the specificities of Zemgale as an agricultural region, home producers are more directed in their activities on flour, meat and herbal products.

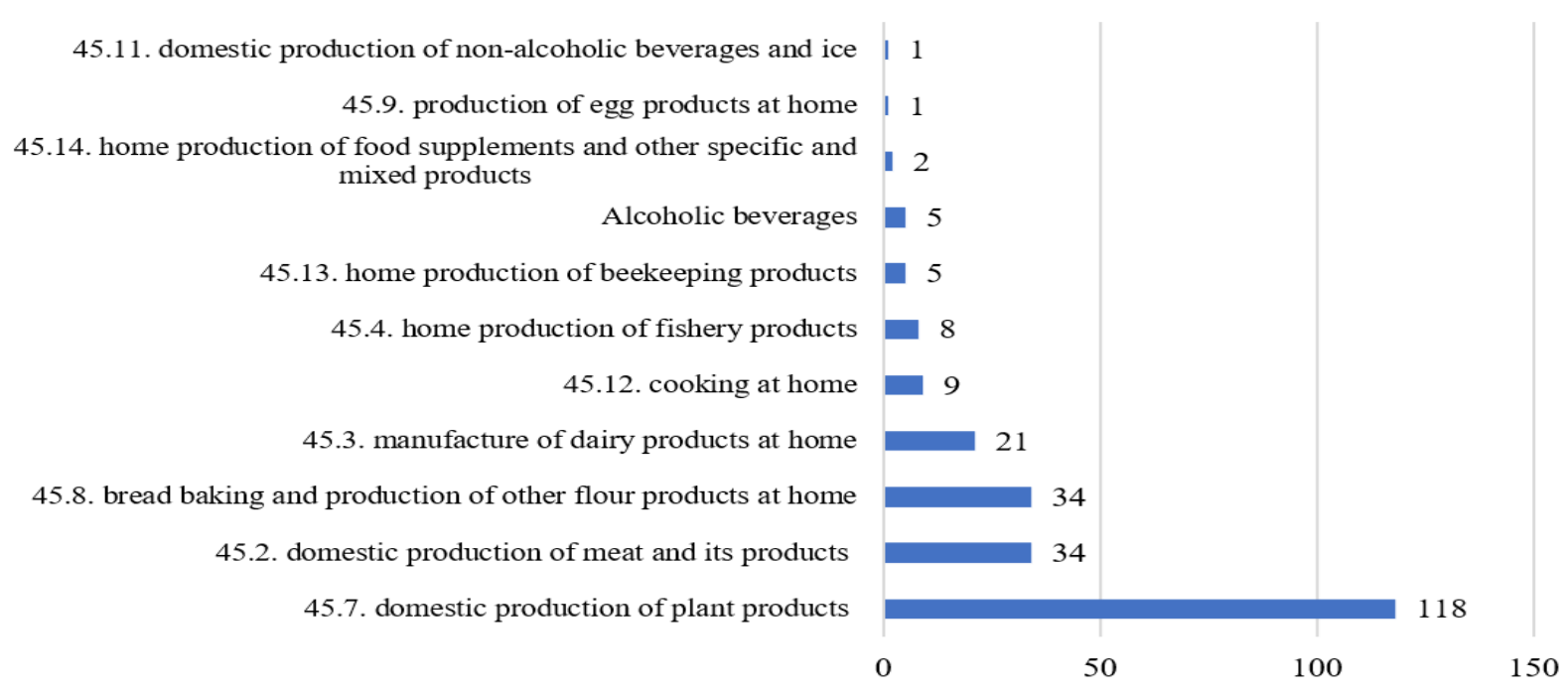

\section{Source: author's calculations based on the data of the FVS}

Fig. 4. Number of homemade food producers in Zemgale region according to food groups, 2021

The analysis of the situation in Zemgale region shows that there are different types of farms and food producers, therefore it is useful to explore what support instruments municipalities provide for the businesses in their territories.

\section{The role of municipalities in LFS}

Concepts of business, food production, and homemade food producers were selected as units of initial analysis of the municipal websites. However, the information networks of the homepages related to the food businesses contained comprehensive information and were linked to tourism and public activities in the context of the local community. In most of the webpages, information on local food producers was found in the sections "Entrepreneurship" and "Tourism". Thus, the information network research revealed municipal activities in two directions: business-related and tourism. Further content analysis in the paper is organized coherently with those two directions. In some municipalities (e.g. Auce, Krustpils and Jekabpils) information on food producers was also included in the thematic sections such as Society, Economy and Investments, Farmers and Entrepreneurs. From the point of view of economic theory, entrepreneurship can be promoted by creating equal, fair conditions for all economic agents and also by promoting certain types of entrepreneurship and economic activities.

Data analysis of the business-related direction shows that entrepreneurs involved in food production are offered different types of support. In municipalities where the number of food producers is higher, also 
support intended directly to food producers is more intense; it should be emphasized, however, that general support measures for local entrepreneurs are important not necessarily focusing on specific economic activities. Data analysis of business support measures in Zemgale municipalities reveals that the main municipal activities are as follows: 1) marketing activities (local trade-marks, organization of a trade, interactive maps and apps, events); 2) relief, competitions and awards; 3) informational activities. Among the examples of marketing activities, the authors can emphasize trade-marks such as "Local producer - a pride of a county" (Jelgava municipality), "Produced in Jelgava county", "Produced in Jaunjelgava county", "Made in the Bauska county". Number of activities aiming to support a trade of homemade food products take place in most of the municipalities in Zemgale region, for example, there is a special shop "Zala Zeme" ("Green Land") in Jelgava county or a number of small local marketplaces across the municipalities. Another approach how to promote local products is interactive online maps and websites, for example www.dobeledara.Iv provides information about small producers in Dobele and Tervete municipalities. Very popular events are festivals of counties and "Uznemeju dienas Zemgale" ("Business days in Zemgale") where local food producers are always invited to promote and sell their products. The research data revieled municipal support for food businesses also in the form of tax reliefs, de minimis support in Jelgava municipality and a number of grant programmes (competitions) for start-ups or awards such as "Piepildi telpu ar ideju", "Esi uznemejs Jelgavas novada", "Bauskas novada uznemeju Gada balva", and "Leciens biznesa" in Krustpils municipality which offered grant money up to 3000 EUR for the implementation of business idea. Municipalities support local business in terms of providing latest information about project schemes and grant programmes. For example, there is an information about discussion seminar on how to distribute local food on the Business-Business (B2B) network (organized by the Ministry of Agriculture), on the solutions found in the Baltic Sea Food project to support local food producers in the rural areas of the Baltic Sea region, information on the Gemoss grant competition for the development, production and development of healthy, innovative foods.

The promotion of local food producers in municipal websites was also identified in the tourism section, which is highlighted on homepages of all municipalities in Zemgale region. This direction can best be described by the local authorities as "information and promotion", which can be found in different information sections, such as sightseeing and farm visits, tourism routs and educational programmes, anf other events. All offers are linked to interactive maps in specific areas. Local food producers are involved in tourism routes, for example, "Satiec saimniekus un izbaudi Bauskas gardumus!" ("Meet the hosts and enjoy the taste of Bauska!"), "Zemgales saimnieces aicina ciemos" ("Zemgale hostesses invite you"), "Uzzini, ka top!" ("Find out it!"), "Celo, iepazisti, atbalsti!" ("Travel, learn about it, and support!"), "Ieaud Zemgales garšu simtgades josta" ("Weave the taste of Zemgale into a hundred-year belt"). The offer of more saturated routes, involving food producers, is in Bauska and Jelgava. Many of the offers are also related to websites at regional and national levels, which expand the agent network of LFS and also promote local products in a wider society. The concept of promotion does not have a specific definition, but its nature involves informing, raising awareness, organising events and attracting participants. Promotion can be defined as a creative process involving advertising, distribution and sales (Eglite A., Kaufmane D., 2019). Another way how to promote local food products is to include food producers in local educational programs, for example, a tour "Grauda cels" ("Grain Road") or tastings of sheep milk products in the farm "Krisjani". Before the COVID-19 pandemic, there was a growing number of farms such as cheese producers, bread bakers and many other opening their doors to visitors in order to introduce and educate people on food crafts. In most cases they were small farms and through the events of tourist attraction the farmers could both sell their products and advertise at relatively low costs. People enjoy observing the process of 
producing products they consume, and visitors pay for both the product and authentic experience of participating, and this combination leads to increased local food awareness. Examples of events for tourists advertised on the websites of local municipalities are, for example, the Mikeldiena market in Jelgava, "Bauskas vecpilsetas pagalmu un Putras godesanas svetki" ("Old Town Courts of Bauska and the Festival of Porridge"), the market for craftsmen and homemade food producers during the festival of Zemgale. The information is focused on the development of local tourism, raising interest in visiting the countryside of Zemgale during the short holidays, while enjoying their culinary heritage, and on foreign tourists who are offered information about Latvian food and local products in an attractive way. Through these activities, the role of the municipal sector in promoting gastronomic tourism is evident, which also involves supporting food producers by providing information on their products and promoting local heritage through festivals, special food, participating in joint projects. Food supply is ensured by entrepreneurs, but the local government, state and non-governmental sector are also involved in cooperation.

Cooperation, as any relationship is not a formal structure, but should be seen as a process that forms and develops. The analysis of activities supporting food producers in the context of cooperation identified cooperation between local government's specialists, particularly between those who are responsible for business and tourism coordination. Municipalities as communities cooperate with each other as well as with other social agents at regional and national levels. Cooperation in projects and informative activities which is normally based on a particular need or on the motivation of participants between local governments and social agents at regional and national level was identified. The research findings revealed that in many cases local actors in rural communities felt responsible for the development of locality therefore implemented initiatives of pooling resources. Some examples are the business-created association "Tervete Home Producers and Craftsmen" ("Tervetes majrazotaji un amatnieki") and cooperation networks between food producers and LEADER partnerships (e.g. partnership "Lielupe" in Jelgava).

The analysis of municipal activities to support local food producers in the context of the COVID-19 pandemic showed that many municipalities in Zemgale have become unifying communities that support and help entrepreneurs to adapt to changing conditions. Examples include measures to trade online under the limited conditions in Ozolnieki municipality, special tourism routes in Bauska municipality named "Travel, learn it, support" and remote business meetings - platforms on cooperation opportunities and development after the pandemic. By comparing local municipal activities in promoting local food, local activities may be grouped in three levels.

1.

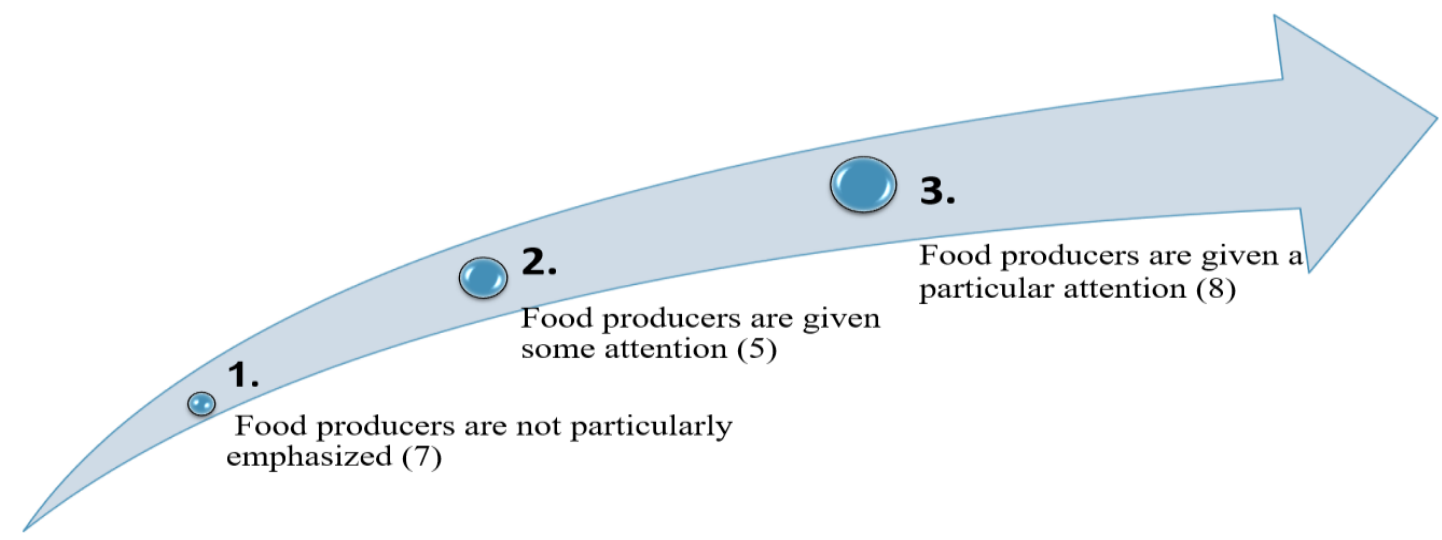

Source: authors' research

Fig. 5. Levels of municipal activities in supporting food producers (number of municipalities) 
At the first level (Figure 5), local food producers are not particularly emphasized by municipalities on their websites: seven municipal homepages provide little and very limited information on food businesses in the county, also little information is available on tourism offer. This is typical for small municipalities or in areas where food producers are few (municipalities of Sala, Ozolnieki, Akniste, Krustpils, Plavinas, Aizkraukle, Rundale). At the second level, food producers are given some attention by local municipalities; however, special measures and marketing activities in this direction are only episodic. The third level is what the researchers have labelled "good practices": in eight of the studied municipalities food producers are especially emphasized and supported. There is also extensive promotion in the tourism direction: special brands, shops and market places, interactive maps and usage of a special term "food craftsmen" to support small producers. The third level is more typical for Bauska, Jelgava Tervete and Dobele municipalities. The homepages of Auce and Iecava municipalities are connected to the interactive food craftsmen map, including offers from small neighbourhoods. In particular, an example of Jelgava municipality must be emphasized in terms of the organisation of business support, information, and activation. Small and medium-sized farms, which are generally more diversified, more innovative and very flexible in creating producer groups and cooperatives, benefit the communities in which they are located, thereby supporting the rural economy. When analysing support activities for food producers on municipal homepages, local networks may be identified (Figure 6) in which home producers, such as associations or rural partnerships, are linked.

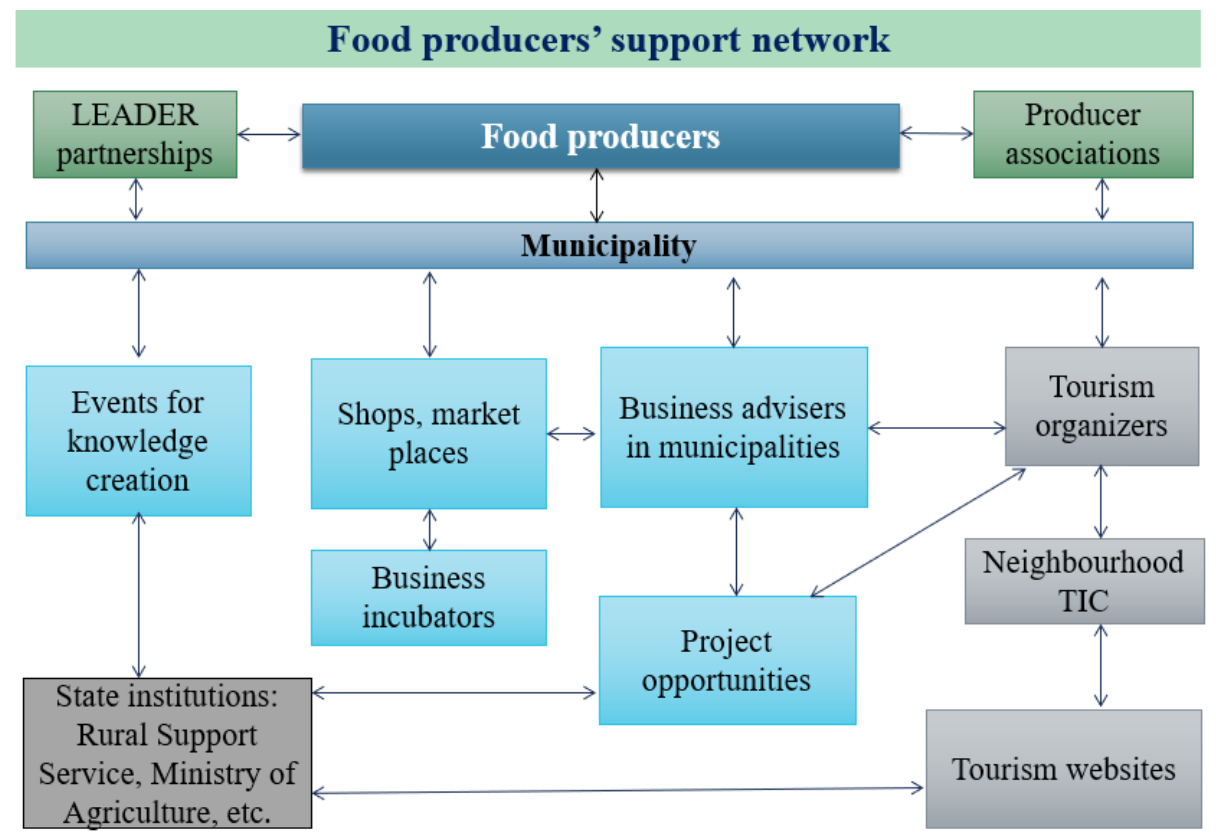

\section{Source: authors' research}

\section{Fig. 6. Food producers' support network in municipalities (based on the authors'} research)

According to the ANT, the local government support networks include both human and non-human actors (Figure 6) such as trading sites and market places, events for new knowledge creation and experience exchange, courses, seminars, business support specialists, and tourism specialists. The analysis of hyperlinks in the homepages of the municipalities shows that the network exits beyond the local borders and incorporates some elements of the regional (tourism information centres, business incubators, project opportunities) and national level, by offering services and information from the Rural Support Service, Latvian Investment and Development Agency, the Ministry of Agriculture, and national tourism websites. 
The data from survey of municipalities show that food producers as entrepreneurs have been spotted and supported by local authorities. As the main economic and social benefits of food producers directly to the county and residents, local government specialists highlighted promoted local patriotism, provided jobs, promotion of the county, and developed tourism. Homemade food production is an opportunity for people in rural areas to generate income from traditional activities, thereby maintaining rural population and promoting rural development. As one of the respondents mentioned: "Personally, I believe that the availability and production of local, traditional food is important for the preservation of national identity, which was also indicated by the study of our municipality on the motivation for the purchase of local food products. As one of the most frequently mentioned reasons for the purchase of local food products, the population mentioned patriotism and the desire to support local producers."

Some of the small producers are becoming successful tourism businesses. By selling their own products, they make their municipalities more visible and recognizable. Small producers also are good examples to local people that homemade food production can be an alternative income source increasing the well-being of their own and that of the county's. The infrastructure around the home production site is often arranged and improved in a way that is becomes a new tourism facility. In the context of sustainability, domestic raw materials grown responsibly and sparing the environment are mainly used in homemade food production.

Business advisers in the survey mentioned several hindering factors which affect the development of homemade food production. Most frequently mentioned factors are low purchasing power of Latvian society, limited market opportunities, reluctance to expand the business and hire employees, tax policy, lack of initiative for joint projects and cooperation on the part of the home producers themselves.

\section{Conclusions, proposals, recommendations}

1) According to the ANT, the local government support networks include both human and non-human actors such as trading sites and market places, events for new knowledge creation and experience exchange, courses, seminars, awards, institutions, business support specialists, and tourism specialists.

2) The content analysis of the information related to the business direction in municipal websites shows that local food producers are being promoted and supported more actively (branding, trademarks, events, seminars, annual awards) in the counties where food craftsmen are more active.

3) The activity levels of local municipalities vary; an experience and strategy identified in the good examples can be used in new municipalities after the administrative territorial reform in June 2021.

4) The analysis of the information related to the tourism direction reveals extended cooperation networks, including local food producers in the tourism system and ensuring the visibility of local food products to a wider consumer groups. The integration of local food into the tourism product develops small and medium-sized business, which contributes specifically to the socio-economic viability of rural communities and the sustainability of the environment, as well as promotes innovation and creativity.

5) According to the point of view of business support specialists in local municipalities, the initiative for joint projects and cooperation on the part of the homemade food producers and food craftmen could increase the competitiveness of their businesses, but a rational review of production and marketing requirements on the part of the country could contribute to both an increase in the number of home producers and would motivate existing producers to extend their business activities thus leading to a positive impact on the economic and social environment of rural areas. 


\section{Acknowledgements}

The paper is based on the results of the research project No LZP-2020/2-0409 "Resilient and sustainable rural communities: multiplier effect of local food system" supported by the Ministry of Education and Science of the Republic of Latvia and Latvian Council of Science.

\section{Bibliography}

1. Bruun, H., Hukkinen, J. (2003). Crossing Boundaries: An Integrative Framework for Studying Technological Change. Social Studies of Science, Volume 33, Issue 1, pp. 95-116.

2. Callon, M., Latour, B. (1981). Unscrewing the Big Leviathan: How Actors Macro-Structure Reality and How Sociologists Help Them to do so. In K. Knorr-Cetina, A.V. Cicourel (Eds.), Advances in Social Theory and Methodology. Toward an Integration of Micro- and Macro-Sociologies (pp. 277-303). Boston: Routledge \& Kegan Paul.

3. Chesterman, A. (2006). Questions in the Sociology of Translation. In J. F. Duarte, A. Rose, T. Seruya (Eds.), Translation Studies at the Interface of Disciplines (pp. 9-27). Amsterdam, NLD: John Benjamins Publishing Company.

4. Devi, W. P., Kumar, H. (2017). Frugal Innovations and Actor-Network Theory: A Case of Bamboo Shoots Processing in Manipur, India. The European Journal of Development Research, Volume 30, Issue 1, pp. 66-83. DOI: $10.1057 / \mathrm{s} 41287-017-0116-1$

5. Eglite, A., Kaufmane, D. (2019). Economic and Environmental Objectives of Tourism in Latvia. In: 19th International Multidisciplinary Scientific GeoConference SGEM 2019. Albena (Bulgaria): Bulgarian Academy of Sciences Sofia, Volume 19, Issue 5.3, pp. 195-202.

6. Fonte, M. (2008). Knowledge, Food and Place. A Way of Producing, a Way of Knowing. Sociologia Ruralis, Volume 48, Issue 3, pp. 200-222.

7. Latour, B. (1996). On Actor-Network Theory. A Few Clarifications Plus More Than a Few Complications. Soziale Welt, Volume 47. Jahrg., H. 4, pp. 369-381.

8. Latour, B. (1997). On actor-network theory. A few clarifications plus more than a few complications. Retrieved from http://www.bruno-latour.fr/sites/default/files/P-67\%20ACTOR-NETWORK.pdf

9. Marin, A., Wellman, B. (2009). Social Network Analysis. Retrieved from https://pdfs.semanticscholar.org/aa4d/5f9ae3fbe6ae16a1de02f7b6daddf615a238.pdf

10. Lee, K. C. L., Newell, J. P., Wolch, J., Schneider, N., Joassart-Marcelli, P. (2014). "Story-Networks" of Livestock and Climate Change: Actors, Their Artifacts, and the Shaping of Urban Print Media. Society \& Natural Resources, Volume 27, Issue 9, pp. 948-963. DOI:10.1080/08941920.2014.918227

11. Roberts, E., Townsend, L. (2016). The Contribution of the Creative Economy to the Resilience of Rural Communities: Exploring Cultural and Digital Capital. Sociologia Ruralis, Volume 56, Issue 2, pp. 197-219.

12. Benedek, Z., Ferto, I., Szente, V. (2020). The Multiplier Effects of Food Relocalization: A Systematic Review. Sustainability, Volume 12, No 9: 3524, pp. 1-18. https://doi.org/10.3390/su12093524

13. Zemgales planosanas regiona nolikums (Zemgale Planning Region Regulations). (2017). Retrieved: https://www.zemgale.Iv/par-zpr/nolikums Access: 18.03.2021.

14. Official Journal of the European Union. (2016). Opinion of the European Economic and Social Committee on 'More sustainable food systems'. Retrieved: https://eur-lex.europa.eu/legalcontent/EN/TXT/PDF/?uri=CELEX:52016AE0232\&from=LV Access: 18.03.2021. 